Recorregut de recerca geològica i mineralògica per la comarca d'Osona (i per les subcomarques del Voltegranès i del Lluçanès): des de Torelló, al Santuari de Bellmunt, a Sant Hipòlit de Voltregà, Sant Boi de Lluçanès i als Munts

Josep Maria Mata-Perelló

Joaquim Sanz Balagué

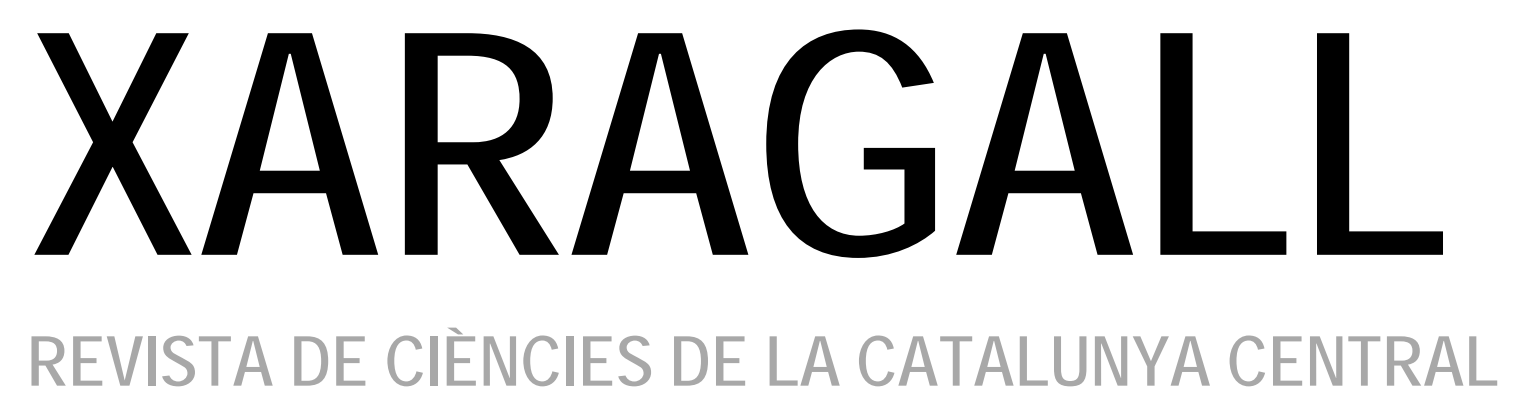

ก. 6

JUNY 2014

Com citar l'article: Mata-Perelló, JM.; Sanz Balaguer, J. Recorregut de recerca geològica i mineralògica per la comarca d'Osona (i per les subcomarques del Voltegranès i del Lluçanès): des de Torelló, al Santuari de Bellmunt, a Sant Hipòlit de Voltregà, Sant Boi de Lluçanès i als Munts. A: XARAGALL. Revista de Ciències de la Catalunya Central. 2014. (n.6). ISSN 2013-4479 DL: B.21483-2009. DOI 


\title{
RECORREGUT DE RECERCA GEOLÒGICA I MINERALÒGICA PER LA COMARCA D'OSONA (I PER LES SUBCOMARQUES DEL VOLTEGRANĖS I DEL LLUÇANÈS): DES DE TORELLÓ, AL SANTUARI DE BELLMUNT, A SANT HIPÒLIT DE VOLTREGÀ, SANT BOI DE LLUÇANÈS I ALS MUNTS
}

\author{
Josep Maria Mata-Perelló \\ Museu de geologia Valentí Masachs, Escola Politècnica Superior d'Enginyeria de Manresa \\ (EPSEM), Universitat Politècnica de Catalunya · BarcelonaTech (UPC), 08272 Manresa, Spain
}

\section{Joaquim Sanz Balagué}

Departament d'Enginyeria Minera i Recursos Naturals (EMRN), Escola Politècnica Superior d'Enginyeria de Manresa (EPSEM), Universitat Politècnica de Catalunya . BarcelonaTech (UPC), 08272 Manresa, Spain

Paraules clau: Depressió geològica de l'Ebre; Catalànids; Materials cenozòics; Patrimoni miner; Patrimoni Geològic

\section{Resum}

Itinerari realitzat el 5 de maig del 2013. Durant el recorregut de l'itinerari efectuarà un tall geològic per diverses sectors de la Catalunya Central (en concret per la comarca d'Osona), per una banda entre la població de Torelló i el Santuari de Bellmunt; i per d'altra entre l'esmentada població de Torelló, Sant Boi de Lluçanès i el Santuari de la Mare de Deu dels Munts. Així, aquest itinerari discorrerà sempre per la Depressió Geològica de l'Ebre (i en concret per la seva Depressió Central) on es troba situada la comarca d'Osona, y especialment els indrets osonencs per on discorrerà el present itinerari. Així, en aquest recorregut anirem trobant diversos afloraments dels materials cenozoics que reblen l'esmenta-la Depressió Geològica de I'Ebre. Aquests materials, dintre del recorregut seran fonamentalment de I'Eocè i de I'Oligocè.

En aquest recorregut, s'efectuaran diverses aturades. Unes de caràcter geomorfològic i altres de caràcter tectònic. Tot i així, també es faran altres aturades de caràcter geològico-ambiental. Tot i així, predominaran les primeres 


\section{Objectius fonamentals}

Els objectius generals del present itinerari, es centraran en els següents aspectes geològics, d'acord amb el sentit de la marxa.

1. Estudi i observació de l'estructura de la Depressió Geològica de l'Ebre, la qual es tallarà al llarg de tot el recorregut de l'itinerari

2. Estudi i descripció dels materials cenozoics (els quals es reparteixen entre l'Eocè i l'Oligocè, amb un clar i net predomini del primer), que formen part del recorregut de I'itinerari. Aquests materials, fonamentalment pertanyen a les següents unitats litoestratigràfiques: Formació Romagars, Formació Gresos de Folgueroles i Formació Vilanova de Sau, Formació Bellmunt, Formació Bracons i Unitat de Puigsacalm

3. Estudi i observació a distancia de l'estructura dels Catalànids (i més exactament de la Serralada Prelitoral Catalana i de la Depressió Prelitoral Catalana), que es situa al Sud del recorregut. I també dels Pirineus, que es situen al Nord del present recorregut. L'itinerari no tallarà cap de les dues unitats geològiques acabades d'esmentar.

4. Estudi i descripció a distancia dels contactes entre les unitats geològiques anteriors: per una banda entre la Depressió Geològica de l'Ebre i els Catalànids; i per d'altra, entre la primera unitat i els Pirineus.

5. Observació de diferents explotacions mineres, antigues i més recents, relacionades amb les mineralitzacions esmentades a l'apartat anterior. Concretament, de les guixeres de Tona, que veurem al començament del recorregut.

6. Observació de les alteracions produïdes sobre el Medi Natural, tant a partir de les explotacions acabades d'esmentar, com de la construcció de grans vials de comunicació, o com les de les explotacions agrícoles.

7. Observació, si s'escau, dels diferents indrets relacionats amb el patrimoni geològic i miner que anirem trobant al llarg del recorregut del present itinerari.

8. A més a més dels anteriorment esmentats. es realitzarà l'observació dels diferents aspectes geològico-ambientals que es trobin al llarg del recorregut.

\section{Antecedents}

Com antecedents parcials del recorregut del present itinerari, farem esment de diversos treballs nostres, corresponents a altres itineraris, concretament dels següents: Mata-Perelló (2007a, 2007b i 2012). També farem esment d'altres itineraris, de Mata-Perelló i Sanz Balagué (1988).

També farem esment del treball, corresponent a altres itineraris, de: Busquets et altri (1979), que inclou recorreguts pels sectors oriental de la comarca d'Anoia, per on discorre part del recorregut del present itinerari.

Com antecedents de caire general, corresponents als trets geològics bàsics, considerarem els treballs de: Guimerà et altri (1992), així com el de Riba (1976). També el de Barnolas et altri (1986), corresponent a fulls geològics, per on discorre la major part de l'itinerari. Finalment farem esment d'altres treballs com: Mata-Perelló (1986) i RIBA et altri (1967). Igualment farem 
esment dels treballs de I"IGME (1982), relatius a les memòries dels fulls geològics per on discorre el present recorregut.

Dintre dels caràcters mineralògics dels indicis per on discorrerà l'itinerari, farem esment d'un antecedent mineralògic general, referit a l'àmbit de Catalunya: Mata-Perelló (1991). Igualment, es pot fer esment del treball de Mata-Perelló, Melgarejo i Soler (1986). Aquest treball fa referència a les mineralitzacions de la comarca d'Osona.

Tots aquests treballs, i d'altres, es trobaran relacionats a l'apartat dedicat a les referències bibliogràfiques, al qual ens remetem.

\section{Recorregut de l'itinerari}

El recorregut de l'itinerari s'iniciarà prop a la població osonenca de Torelló. Des d'aquí, el recorregut es dirigirà cap a Sant Pere de Torelló, passant molt a prop de Sant Vicenç de Torelló. Tot seguit, des de Sant Pere de Torelló, el recorregut de l'itinerari pujarà cap al Santuari de Bellmunt, on s'efectuaran diverses parades en torn al mateix. Posteriorment el recorregut retornarà a Torelló, des d'on s'anirà cap a Sant Hipòlit de Voltregà. Posteriorment es dirigirà cap a Sant Boi de lluçanès i cap el Santuari de la Mare de Deu dels Munts. En aquest indret finalitzarà el recorregut de l'itinerari, després de realitzar-se la darrera aturada.

\section{Advertiments previs}

A l'igual que en altres ocasions, en altres recorreguts de RECERCA GEOLÒGICA I MINERALÒGICA ..., si es disposa del temps suficient, poden efectuar-se passant per totes les parades i filloles. En cas contrari, recomanem prescindir de les anomenades PARADES CONDICIONALS.

Pel que fa al recorregut de l'itinerari, cal dir que la seva major part s'efectuarà per recorreguts que es troben en bon estat de conservació. Tot i així, es faran petits trams per pistes en irregular estat de conservació, de curt recorregut, que si s'escau, es podran fer a peu.

Finalment, i per d'altra banda, recomanem tenir una especial cura de respecte a la natura, al llarg de tot el recorregut.

\section{Descripció de l'ítinerari}

En aquest recorregut hem situat, com ja és habitual en tots els itineraris, una sèrie d'ESTACIONS o de PARADES, que anirem veient a continuació. En cada cas, els hi donarem una denominació que podrà correspondre a algun paratge proper. També indicarem el terme municipal i la comarca on es troba. Per d'altra banda, en cadascuna de les parades, indicarem entre parèntesi el número del mapa topogràfic de la Cartografia Militar de España, a escala 1:50.000, on es troba situada la parada considerada. En aquesta ocasió utilitzarem els dos següents fulls: 294 (o full de Manlleu) i 332 (o de Vic). Així doncs, la relació ordenada de les diferents parades que composen el recorregut del present itinerari, són les següents: 


\subsection{Parada 1. COLL DE L'HOSTAL DEL MAL GOVERN (terme municipal de Sant Pere de Torelló, comarca d'Osona). (Full 294).}

El recorregut de l'itinerari, I'iniciarem a la població osonenca de Torelló. Des d'aquí, ens caldrà anar cap a Sant Vicenç de Torelló. Després, ens caldrà anar cap a Sant Pere de Torelló. A partir d'ara ens caldrà seguir per la carretera B - 5224, fins a trobar el trencall d'on eix el camí del Santuari de Bellmunt, passant-se pel Coll de I'Hostal del Mal Govern. En aquest indret farem una nova aturada, després d'un llarg recorregut d'uns $10 \mathrm{Km}$, des de l'inici.

En aquest recorregut, després de passar el poble de Torelló (o més exactament el de Sant Vicenç de Torelló), es comencen a trobar nivells de llims molt sorrencs de color gris blavós, marins com els anteriors, que pertanyen a la denominada Sots-unitat Puigsacalm Mig.

Cap els voltants de la Masia de la Redortra, hi afloren els gresos gris-blavosos, alternant amb capes de calcolutites (de tonalitats similars), que ja pertanyen a la Sots-unitat Puigsacalm Inferior. Aquest mateixos materials són els que trobem al Coll de l'Hostal del Mal Govern, per on fem la present aturada. Per d'altra banda, s'ha passat d'un cabussament gairebé horitzontal (pels voltants de Torelló i poc després de Sant Pere de Torelló), a un cabussament inclinat cap a sud, que és el que correspon als materials que es troben prop de la present parada, de prop de 25 graus. (fotografia 1).Tanmateix, mirant des d'aquest indret cap amunt, es pot veure que els materials es van verticalitzant cada cop més cap al Nord. (fotografies 2 i 3).

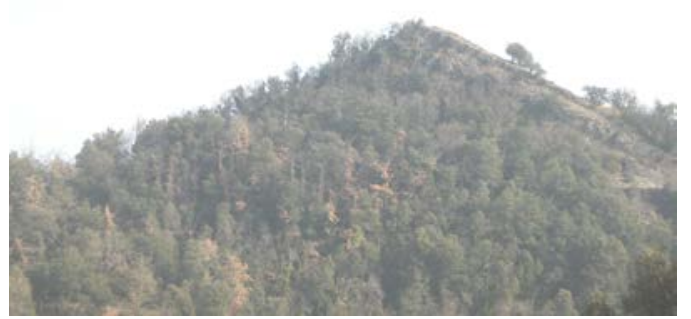

Fotografia 1. Aspecte del cabussament cap al Sud, a migjorn del Santuari de Bellmunt

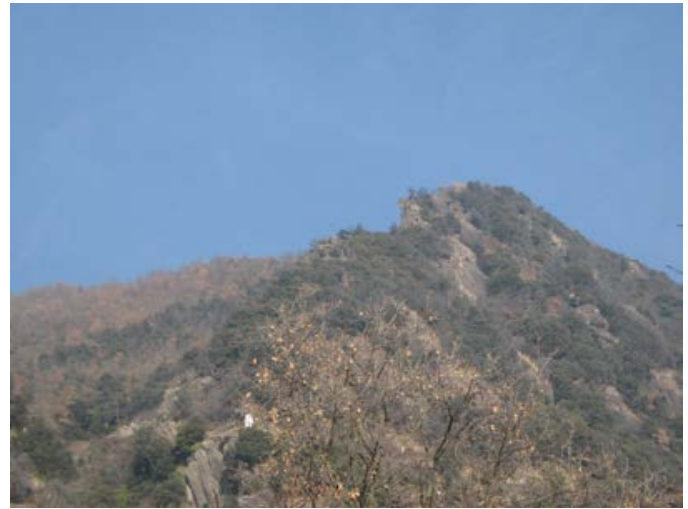

Fotografia 2. Materials verticalitzats, prop del Santuari 


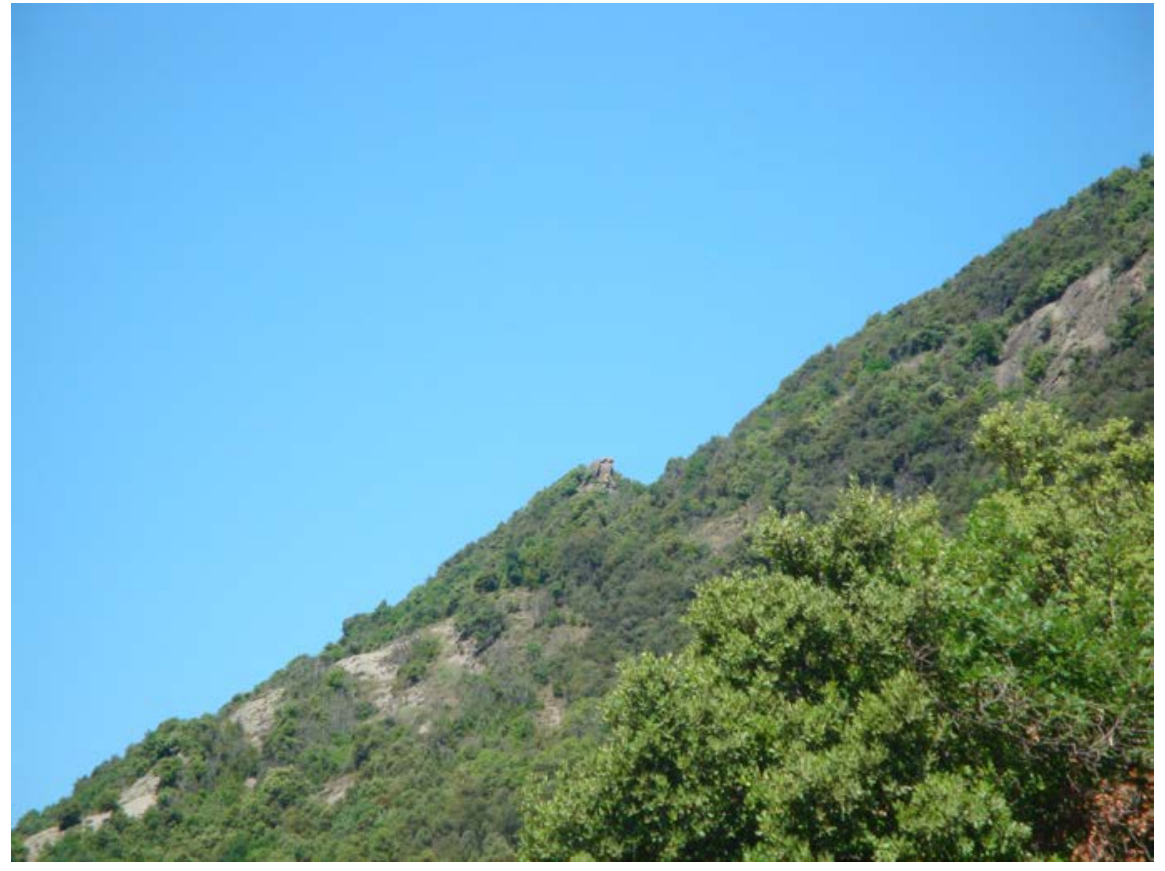

Fotografia 3. Un aspecte dels nivells eocènics, cabussant cap al Sud

\subsection{Parada 2. FONT DE LA VIDRANESA, (terme municipal de Sant Pere de Torelló, comarca d'Osona). (Full 294).}

Des de la parada anterior, caldrà continuar cap al Santuari de Bellmunt; així, es passarà primer pel Mirador del Pedronet de Montserrat; i després per la Font Vidranesa, on caldrà efectuar la present parada. Així, des de la parada anterior, caldrà fer un recorregut aproximat de poc més de $2,5 \mathrm{Km}$ per tal d'arribar fins a aquest lloc, on es farà la quarta parada d' aquest recorregut.

En principi, en aquest recorregut s'han anat tallant els materials abans esmentats a la parada anterior. Tot i així, prop del Pedronet de Montserrat, adquireixen un caràcter detrític, cada cop més marcat.

Per d'altra banda el seu cabussament de les capes s'ha anat fent cada vegada més acusat, i arriba en aquest indret a ésser d'uns 65 graus, trobant-se els estrats inclinats cap al sud. Ara, en aquets darrers trams, s'han anat tallant uns nivells de gresos, que alternen amb conglomerats. Aquests materials, també pertanyen a la Sots-unitat Puigsacalm Inferior, i presenten un marcat color grisenc.

Per d'altra banda, al poc de passar la font, comença a trobar-se una alternança de gresos silícics de ciment carbonatat i de calcolutites rogenques. Aquests altres materials ja pertanyen a la Formació Bellmunt, i són inferiors als de la unitat acabada de veure.

Prop de l'esmentada Font de la Vidranesa, i tot continuant ascendint cap al Santuari de Bellmunt, es traspassa el nucli de I'Anticlinal de Bellmunt; i més enllà els estrats cabussen cap al nord, amb una forta inclinació propera als 70 graus. Aquest anticlinal, constitueix l'estructura més septentrional de l'Avant-país de la Depressió Geològica de l'Ebre, i la més propera a I'Encavalcament de Vallfogona. de Voltregà, Sant Boi de Lluçanès i als Munts 
Es tracta de un clar exponent de la component septentrional (la Pirinenca) d'aquestes estructures. Tanmateix, com a conseqüència d'aquestes estructures, l'eix de l'anticlinal no coincideix amb el de la serra, presentant-se al sud de la mateixa, donada la component septentrional de les forces pirinenques, que decanten l'anticlinal cap el sud.

Per últim, cal dir que aquest anticlinal, del qual acabem de parlar, presenta un clar arrumbament de direcció Est-Oest.

\subsection{Parada 3. SANTUARI DE BELLMUNT, (terme municipal de Sant Pere de Torelló, comarca d'Osona). (Full 294).}

Des de la parada anterior, cal continuar pel camí cap al proper Santuari de Bellmunt. En un principi s'arribarà a l'aparcament del final del tram transitable del camí. I, després caldrà ascendir a peu cap al santuari esmentat, que es troba al punt més alt del recorregut de I'itinerari, a $1.247 \mathrm{~m}$. S'hi arriba fent un recorregut d'uns $250 \mathrm{~m}$.

Des de la parada anterior, es pot veure com ha variat el cabussament dels materials, en haver passat al flanc septentrional de l'anticlinal esmentat anteriorment. En bona part d'aquest recorregut hem trobat els nivells rogencs de la Formació Bellmunt. Per d'altra banda, dalt del Santuari de Bellmunt, es tornen a trobar els nivells de gresos (alternants amb conglomerats), que pertanyen a la Sots-unitat del Puigsacalm Inferior. Com ja hem dit, aquests materials formen part del flanc septentrional de I'Anticlinal de Bellmunt, i ja els havíem trobat abans d'arribar a la Font de la Vidranesa, a la parada anterior.

En aquest indret, es pot gaudir d'un bon exemple de relleu invertit (o d'inversió de relleu), ja que el nucli de I'Anticlinal de Bellmunt es troba situat a una cota sensiblement inferior a la del Santuari de Bellmunt, on ara ens trobem, i que forma part del flanc meridional de I'anticlinal anteriorment esmentat. És a dir: es troben al nucli en una posició topogràficament inferior a la d'un dels flancs, al contrari de com hauria d'ésser. (fotografia 4). Això ens indica que la força que ha produït el plegament és pirinenca, procedent del Nord.

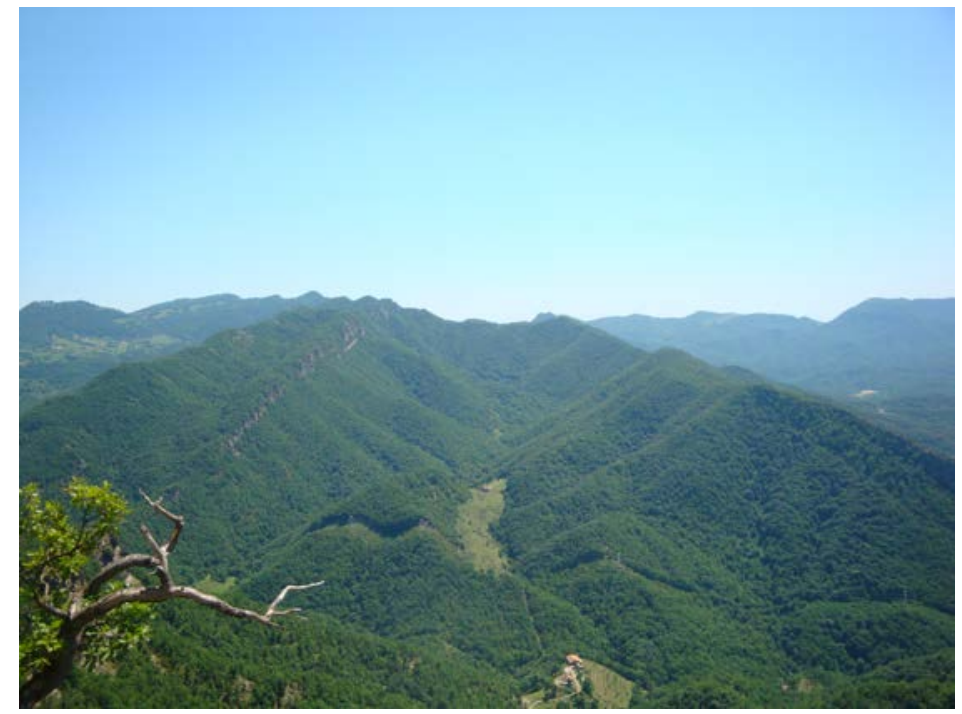

Fotografia 4. Serra de Milany des del Santuari de Bellmunt. Anticlinal de Bellmunt

Xaragall.2014 n.6 | Recorregut de recerca geològica i mineralògica per la comarca d'Osona (i per les subcomarques del Voltegranès i del Lluçanès): des de Torelló, al Santuari de Bellmunt, a Sant Hipòlit de Voltregà, Sant Boi de Lluçanès i als Munts 
Per d'altra banda, des del Santuari de Bellmunt, es pot veure la inversió del relleu, ja que la part més esfondrada correspon a la xarnera del plec.

\subsection{Parada 4 - CONDICIONAL. PLA DE MASFERRER, (terme municipal de les Masies de Voltregà, subcomarca del Voltreganès, comarca d'Osona). (Full 294).}

Després de realitzar la parada anterior, cal retornar enrere, fins arribar a Torelló. Tot seguit, cal continuar per la carretera - autovia C - 17, fins a trobar el trencall de Sant Hipòlit de Voltrega i de Masies de Volttrega. Després, ens caldrà continuar per la carretera local BV - 4808, que condueix cap a Sant Boi de Lluçanès. En arribar al Pla de Masferrer, farem una nova aturada, aproximadament a uns $15 \mathrm{Km}$ de la parada anteriorment realitzada.

En aquest recorregut, hem anat trobant afloraments dels materials esmentats a les aturades anteriors, els quals pertanyen a la Depressió Geològica de I'Ebre, on continuem estant situats en aquest indret. Així, hem trobat nivells, grisencs, de calcolutítics i de gresos carbonatats de la Unitat Puigsacalm, i més concretament de la denominada Sots-unitat Puigsacalm Superior.

\subsection{Parada 5. SORTIDA DE SOBREMUNT, EL COLLET, (terme municipal de Sobremunt, subcomarca del Lluçanès, comarca d'Osona). (Full 331).}

Després de realitzar la parada anterior, ens cal continuar per la carretera BV - 4608, anant cap a Sant Boi de Lluçanès. Més endavant, per l'esquerra, trobarem el trencall de la carretera que es dirigeix cap a Sobremunt, la BP - 4607. En arribar a aquest darrer poble, ens caldrà sortir del mateix, cap el Sud, pel camí que es dirigeix cap a la Riera de Sorreig, Quasi a la sortida del poble, prop del collet, farem una nova aturada, després de recórrer uns $10 \mathrm{Km}$ des de la parada anterior.

En aquest recorregut, hem anat trobant afloraments dels materials esmentats a les aturades anteriors. Tot i així, prop de l'indret de l'aturada, haurem trobat nivells continentals de tonalitats ocres, amb gresos i calcolutites. Des d'aquest indret, mirant cap el Nord, es poden veure de nou els relleus dels voltants del Santuari de la Mare de Deu dels Munts, per darrera dels quals es veuen els relleus pirinencs del Puigmal. (fotografia 5).

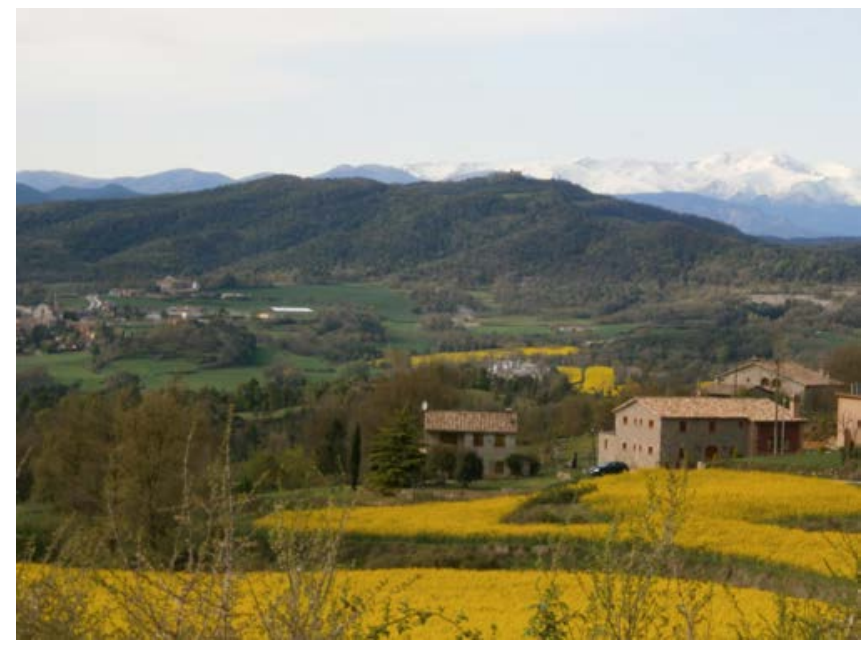

Fotografia 5. Els Munts, des de Sobremunt. I més al fons: el Puigmal

Xaragall.2014 n.6 | Recorregut de recerca geològica i mineralògica per la comarca d'Osona (i per les subcomarques del Voltegranès i del Lluçanès): des de Torelló, al Santuari de Bellmunt, a Sant Hipòlit de Voltregà, Sant Boi de Lluçanès i als Munts 


\subsection{Parada 6. MARE DE DEU DELS MUNTS, (terme municipal de Sant Agustí de Lluçanès, comarca d'Osona, subcomarca del Lluçanès). (Full 294).}

Després de realitzar l'aturada anterior, cal retornar a la carretera BV - 4608. Així, arribarem a Sant Boi de Lluçamès. Més endavant, arribarem a la cruïlla amb la carretera local BV - 4653 (procedent de Perafita). En trobar-la, ens caldrà seguir per ella, tot anant ara cap el Nord, cap a Sant Agustí de Lluçanès. Més endavant, deixarem a la dreta el trencall de la carretera local que es dirigeix cap a Sant Boi de Lluçanès. En tot cas, ens caldrà seguir cap al Nord. Ben aviat, trobarem per la dreta, el trencall que es dirigeix cap al Santuari de la Mare de Deu dels Munts, cap on ens caldrà anar. En arribar-hi, farem una nova aturada, després de recórrer uns $8 \mathrm{Km}$ des de la parada anteriorment realitzada.

En aquest recorregut, hem continuat trobant afloraments dels materials cenozoics esmentats a les aturades anteriors. Cap a les immediacions del Santuari, hem trobat afloraments d'uns nivells de gresos (sovint conglomerats) i calcolutites, que pertanyen a l'Eocè, concretament al Bartonià. Aquests materials formen part de l'extrem occidental de l'Anticlinal de Bellmunt.

Aquest indret, força enlairat, ens permet fer una bona observació dels relleus situats entorn d'on ara som. Així, mirant cap a llevant es poden veure els relleus del Vidranès, de Bellmunt i del Cabrerès, amb el Coll sa Cabra. (fotografia 6).

Mirant cap el Nord, es poden veure els relleus de la Corbatera, Sant Quirze de Besora i Montesquiu; així com de bona part del conjunt del Bisaura, al Nord de la comarca d'Osona. (fotografia 7). Tanmateix, mirant cap el Sud, es poden veure els relieves en cuesta dels voltants de Sant Boi de Lluçanès i la Trona (fotografia 8). Així, aquest indret constitueix un bon lloc d'observació de tots els voltants.

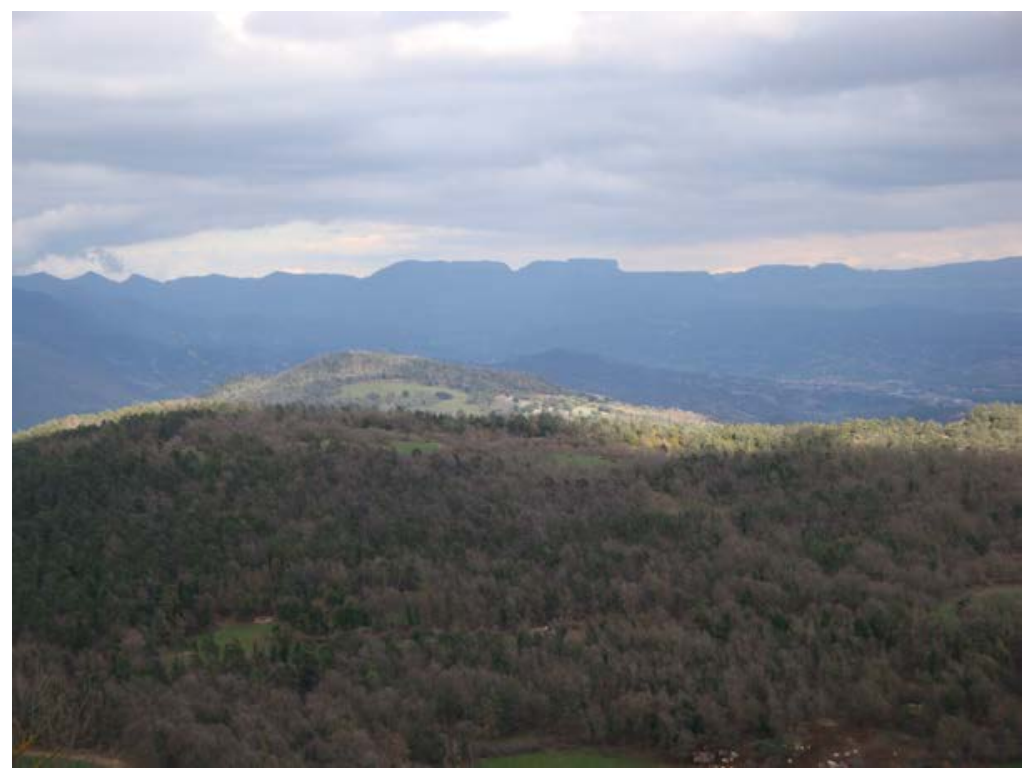

Fotografia 6. Relleus del Vidranès, de Bellmunt i del Cabrerès, des de la Mare de Deu dels munts

Xaragall.2014 n.6 | Recorregut de recerca geològica i mineralògica per la comarca d'Osona (i per les subcomarques del Voltegranès i del Lluçanès): des de Torelló, al Santuari de Bellmunt, a Sant Hipòlit de Voltregà, Sant Boi de Lluçanès i als Munts 


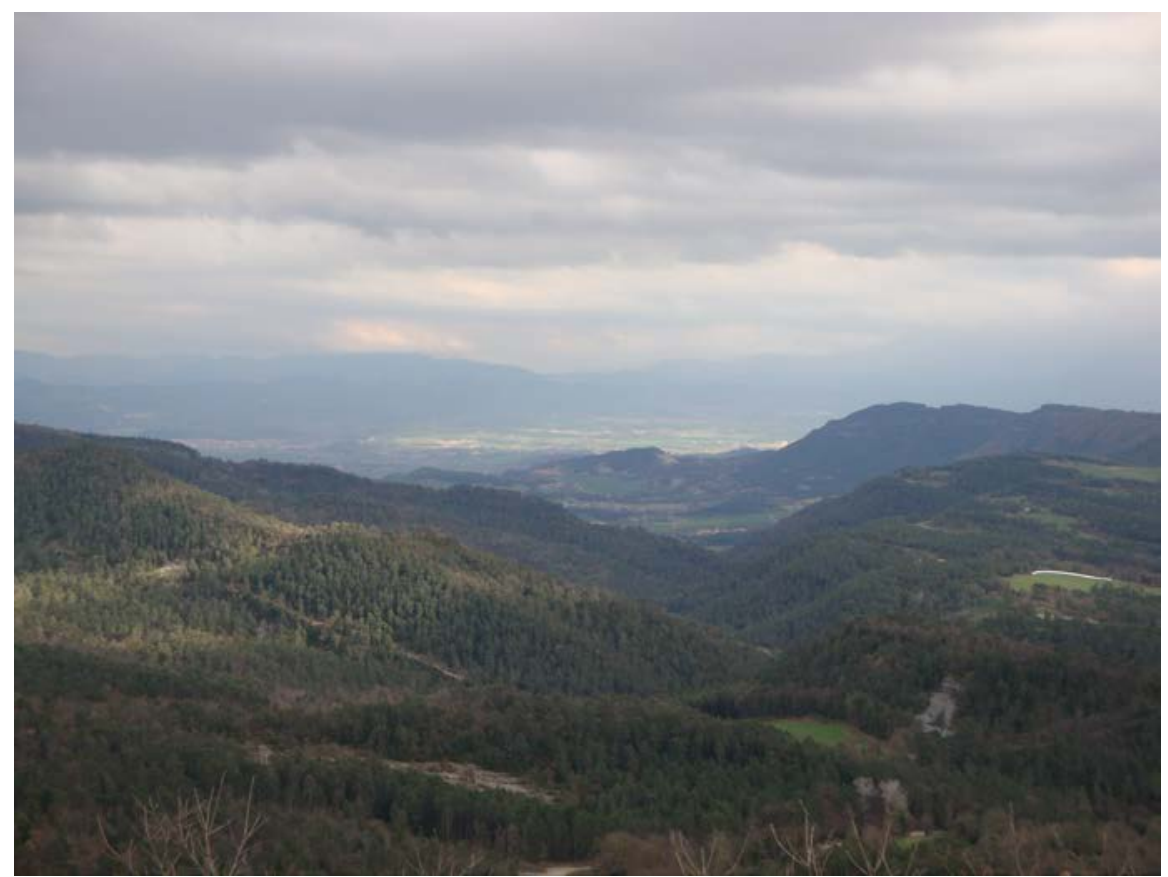

Fotografia 7. Relleus dels voltants de la Corbatera, Montesquiu i la Bisaura, des de la Mare de Deu dels Munts

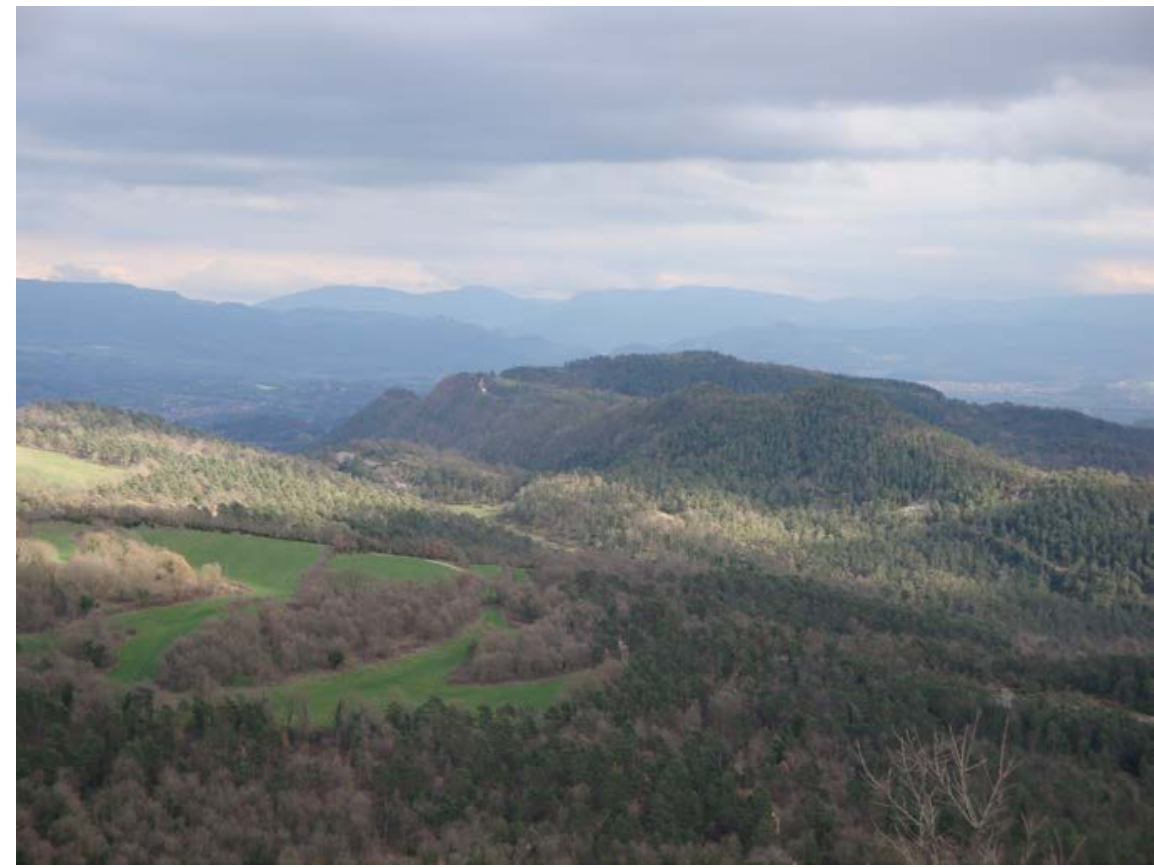

Fotografia 8. Relleus de Sant Boi de Lluçanès i de la Trona, des de la Mare de Deu dels Munts

\section{En aquest indret finalitza el recorregut.}

Xaragall.2014 n.6 | Recorregut de recerca geològica i mineralògica per la comarca d'Osona (i per les subcomarques del Voltegranès i del Lluçanès): des de Torelló, al Santuari de Bellmunt, a Sant Hipòlit de Voltregà, Sant Boi de Lluçanès i als Munts 


\section{Bibliografia}

BARNOLAS, A. et altri (1986).- Mapa Geológico de España a escala 1:50.000. Hoja y explicación no 332 (Vic). Ins. Geol. Mi. España. Minist. Indústria y Energia. Madrid

BUSQUETS, P. et altri (1979).- Geologia d'Osona, Publicacions de I'Escola Universitària de Mestres d'Osona. Vic

GUIMERÀ, J. et altri (1992).- Geologia (II), Història Natural dels Països Catalans, Vol. 2, 547 pag. Enciclopèdia Catalana, S.A. Barcelona

IGME (1982).- Mapa Geológico de España a Escala 1:50.000 (2a Serie). Hoja y Memoria $\mathrm{n}^{\circ} \underline{32}$ (Vic). Inst. Tecnológico y GeoMinero de España. Minist. Indus. Ener. Madrid.

MATA-PERELLÓ, J,M. (1986).- Depressió Geològica de I’Ebre, o Depressió Central Catalana?. Revista Dovella, n 35, pp. 85-90, Manresa

MATA-PERELLÓ, J.M. (1991).- Els Minerals de Catalunya. Arxius de la Secció de Ciències, t. XCIII, Institut d’Estudis Catalans. Barcelona

MATA-PERELLÓ, J.M. (2007a).- Recorregut de recerca geològica i mineralògica per la Comarca d'Osona: des de Tona a Taradell, Sant Sadurní d'Osormort, Torelló, Bellmunt i el Coll de Bracons. Inèdit, 16 pag. Manresa

MATA-PERELLÓ, J.M. (2007b).- Recorregut de recerca geològica i mineralògica per les comarques del Bages, Moianès i Osona: des de Manresa a Calders, Moià, Collsuspina, Tona, Torelló i al Santuari de Bellmunt. Inèdit. 12 pàgines. Manresa

MATA-PERELLÓ, J.M. (2012).- Recorregut de recerca geològica i mineralògica per la comarca d'Osona: des de Tona cap a Torelló, al santuari de Bellmunt i al coll de Bracons. Inèdit. 12 pàgines. Manresa

MATA-PERELLÓ, J.M; MELGAREJO, J.C. i SOLER, A. (1986).- Inventari Mineralògic de la comarca d'Osona. Xaragall, 15. Manresa

MATA-PERELLÓ, J.M. i SANZ BALAGUÉ, J. (1988).- Guia d'Identificació de Minerals (Països Catalans i d'altres). Edit. Parcir, 205 pag. Manresa

RIBA ARDERIU, O. (1967).- Resultado de un estudio sobre el terciario continental de la parte Este de la Depr. Central. Acta Geol. Hispánica, t. II, nº 1. pp. 3-4. Barcelona

RIBA ARDERIU, O. Et altri. (1976).- Geografia física dels Països Catalans. Edit Ketres. Barcelona 